\title{
Subjektivitet ved sykmelding 粦
}

\author{
Personer som oppsøker helsevesenet med behov for sykmelding har ofte uspesifikke helseplager med \\ sammensatte årsaksforhold. Folketrygden har klare regler om at nedsatt arbeidsevne skal skyldes sykdom \\ eller skade. Trygdemedisinske vurderinger skjer i krysspunktet mellom pasientens subjektive opplevelse og \\ legens objektive medisinske vurderinger. Målet med kronikken er å sette søkelyset på et tydelig misforhold \\ mellom lovverk og sykmeldingspraksis, der legens subjektivitet sjelden blir diskutert.
}

\author{
Irene Øyeflaten \\ irene.oyeflaten@air.no \\ AiR - Nasjonalt kompetansesenter \\ for arbeidsretta rehabilitering \\ Rauland \\ og \\ Psykologisk institutt \\ Universitetet i Bergen
}

Engelsk oversettelse av hele artikkelen på nett www.tidsskriftet.no

Det er nødvendig med retningslinjer for hvem som har rett til lønnskompensasjon når de ikke er i stand til å utføre arbeidet sitt. Nedsatt arbeidsevne kan være påvirket av individets helse, men er også knyttet til samspill med omgivelsene og hvilke krav arbeidstakeren stilles overfor i sin jobb. Regelverk for sykmelding og andre trygdeytelser er imidlertid basert på krav om at personens funksjonsnedsettelse skal skyldes sykdom eller skade (1). Det er legen som attesterer at de medisinske vilkårene er oppfylt.

I rollen som medisinsk sakkyndig skal legen tilstrebe størst mulig grad av objektivitet og nøytralitet (2). Dette objektivitetsidealet er basert på en tradisjonell naturvitenskapelig sykdomsforståelse der sykdom er en målbar størrelse. Selv om det er bred enighet om at nedsatt arbeidsevne er basert på komplekse årsakssammenhenger, synes det i trygdelovverket å være en overdreven tro på helsevesenets evne til å bestemme om funksjonsnedsettelsen skyldes objektiv sykdom. En slik naturvitenskapelig tilnærming kommer til kort som forklaringsmodell for uspesifikke helseplager med sammensatte årsaksforhold. Dette er problematisk, fordi uspesifikke helseplager uten observerbar patologi eller objektive funn ofte er et kjennetegn ved langtidssykmeldte personer (3). I sykmeldingspraksis representerer pasientens opplevelse det subjektive og legens vurdering det objektive. Legen må også utøve profesjonelt skjønn, noe som kan innebære ulike former for subjektive vurderinger $(4,5)$.

Målet med denne kronikken er å drøfte hvordan objektivitets- og subjektivitetsbegreper blir ivaretatt i sykmeldingspraksis, og hvordan de er relatert til faglig skjønn. Folketrygdloven kapittel 8 om sykepenger blir lagt til grunn for diskusjonen (1), men hovedpunktene i diskusjonen gjelder like gjerne for andre helserelaterte ytelser. Jeg ønsker også å belyse sykmeldingspraksis sett i forhold til diagnoseklassifiseringssystemer og forståelser av sykdomsbegrepet.

\section{Objektivitet og subjektivitet}

Solli har operasjonalisert ulike objektivitetsog subjektivitetsbegreper som trygdemedisinen anvender (4) (tab 1). Objektivitet og subjektivitet studeres både ontologisk (læren om det som er) og kunnskapsteoretisk (4). Fire begreper som fremkommer i tabellen kan eksemplifiseres medisinsk på følgende måter: Ontologisk objektivitet baserer seg på en tradisjonell naturvitenskapelig tenkning. Ifølge denne avsetter sykdom medisinsk påvisbare spor i det syke menneskets kropp. Ontologisk subjektivitet er det som kun eksisterer avhengig av bevisstheten, for eksempel opplevelse av smerte. Krav om at en helseplage må oppfylle visse kriterier for å kunne tilfredsstille en spesifikk sykdoms- diagnose, er et eksempel på anvendelse av kunnskapsteoretisk objektivitet. Når legen i sin sykmeldingspraksis gjør vurderinger av ikke-medisinsk karakter, kan disse sies å være kunnskapsteoretisk subjektive.

\section{Sykmeldingspraksis \\ Folketrygdloven}

For å ha rett til sykepenger er det ikke tilstrekkelig å være arbeidsufør. I folketrygdloven § 8-4 går det frem at arbeidsuførhet på grunn av en funksjonsnedsettelse klart skal skyldes sykdom eller skade (1). Arbeidsuførhet som skyldes livsproblemer eller sosiale, økonomiske eller andre problemer, gir i utgangspunktet ikke rett til sykepenger. Det kan imidlertid være uklare grenser mellom tilstander forbundet med en vanskelig livssituasjon og sykdommer i medisinsk forstand. På den ene siden blir det i et rundskriv fra rettskildene for folketrygdloven vektlagt at tilstander knyttet til livsproblemer ikke bør sykdomsforklares, og at en tendens til utglidning av praksis må forhindres via en innskjerping av de medisinske vilkårene (6). På den annen side åpnes det for bruk av medisinsk klokskap og klinisk skjønn og at en sykmelding i enkelte tilfeller kan forebygge en lengre sykdomsperiode (6). I veilederen i trygdemedisin er legen som fyller ut sykmeldingsattest og legeerklæring underlagt en rekke krav til

Tabell 1 Objektivitets-og subjektivitetsbegreper i trygdemedisinen (4)

\begin{tabular}{|c|c|c|}
\hline & Ontologisk & Kunnskapsteoretisk (epistemologisk) \\
\hline Objektivt & $\begin{array}{l}\text { Ontologisk objektivitet } \\
\text { - ting } \\
\text { - uavhengig av menneskelig } \\
\text { bevissthet eller kunnskap }\end{array}$ & $\begin{array}{l}\text { Kunnskapsteoretisk objektivitet } \\
\text { - saklighet } \\
\text { - upartiskhet } \\
\text { - nøytralitet } \\
\text { - nøyaktighet } \\
\text { - intersubjektivitet } \\
\text { - allmenngyldighet }\end{array}$ \\
\hline Subjektivt & $\begin{array}{l}\text { Ontologisk subjektivitet } \\
\text { - avhengig av bevisstheten }\end{array}$ & $\begin{array}{l}\text { Kunnskapsteoretisk subjektivitet } \\
\text { - usaklighet } \\
\text { - partiskhet } \\
\text { - unøyaktighet } \\
\text { - vilkårlighet }\end{array}$ \\
\hline
\end{tabular}




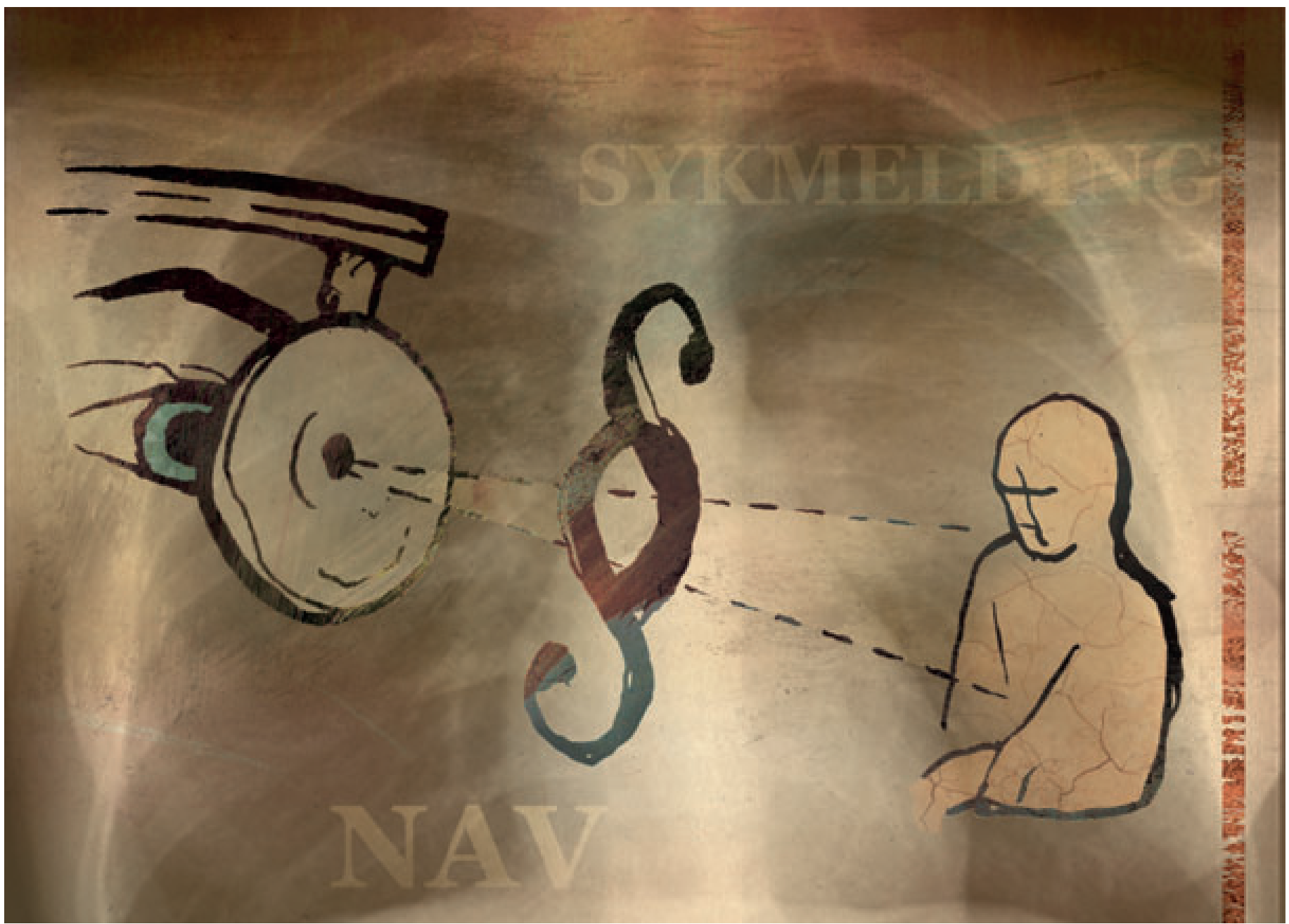

Illustrasjon Stein Løken

korrekthet, upartiskhet og bruk av faglig skjønn (2). I legeerklæringen bør kilde for opplysninger fremgå, og skillet mellom pasientens subjektive symptomer og legens objektive funn bør komme tydelig frem (2). Det presiseres videre at legen skal legge frem de faktiske medisinske forhold i form av objektivt verifiserbare medisinske fakta, og at disse bør skilles best mulig fra legens egne vurderinger og synspunkter. I den medisinske fremstillingen er det viktig at legen verken opptrer som forsvarsadvokat for pasienten eller som vokter av systemet (2). I de skjønnsmessige vurderingene er det derfor påkrevd at legen ikke lar fremstillingen bli farget av egen oppfatning av hva som ville være et rettferdig eller hensiktsmessig utfall (2).

Ut fra Veileder i trygdemedisin 2010 (2) blir det tydelig at den trygdemedisinsk sakkyndige innehar en vanskelig dobbeltrolle. Legen skal sørge for at regelverket følges ved at de medisinske vilkårene er oppfylt, samtidig som det gis rom for skjønnsmessige vurderinger.

Legen skal altså sørge for at de medisinske vilkårene er oppfylt, og som grunnregel skal sykmelding være basert på påvisbar sykdom. Men hva er sykdom? Svaret på dette spørsmålet avhenger blant annet av hvilket perspektiv vi har - som pasient, profesjonell eller forvalter av samfunnets goder (7). Legens perspektiv vil i stor grad være knyttet til medisinsk praksis. Kunnskap om sykdom oppstår gjennom forsøk på å finne årsaker og behandling for sykdom (7). Hvordan er det da med sykmeldingspraksis? Er det slik at legen i sin sykmeldingspraksis kan støtte seg til et sykdomsbegrep definert av folketrygden?

\section{Sykdomsbegrepet}

Selv om sykdomsbegrepet er sentralt i trygdelovgivningen, inneholder ikke loven noen definisjon av begrepet (6). Hvorvidt noe defineres som en sykdomstilstand, vil være avhengig av hvordan den medisinske vitenskapen til enhver tid utformer sykdomsbegrepet og den praksis som har utviklet seg på området (6). Trygderetten opprettet i 1993 en «konsensusgruppe om sykdomsbegrepet» som skulle vurdere hvordan folketrygdens lovtekst fungerte når det gjaldt diffuse muskel- og skjelettlidelser, lettere psykiske lidelser og psykososiale problemer i uføresaker. Konsensusgruppens hovedkonklusjon var at medisinsk vitenskap ikke vil kunne bidra til en trygdemessig operativ avklaring av sykdomsbegrepet (8).

\section{Diagnosesystemet}

Diagnosekoding er påkrevd på sykmeldingsattester. Medisinske årsaker til nedsatt arbeidsevne blir kodet i ulike kodesystem innen primær- og spesialisthelsetjenesten, der begge klassifiseringssystemene har koder både for sykdomsdiagnoser og såkalte symptomdiagnoser. Ikke alle diagnoser viser til en sykdom i objektiv forstand. For å få en sykdomsdiagnose er hovedregelen at det må finnes påvisbar patologi. Det betyr at kravet til ontologisk objektivitet er innfridd. Andre diagnoser, såkalte syndromer (9), kan sies å basere seg på kunnskapsteoretisk objektivitet, ved at visse allmenngyldige kriterier må være innfridd for å sette en medisinsk merkelapp. Symptomdiagnoser baserer seg derimot utelukkende på pasientens ontologiske subjektivitet. Det er ikke alle diagnoser som gir rett til sykepenger selv om de er konsultasjonsgrunn. Dette gjelder spesielt ulike sosiale problemer, der folketrygdloven har tydeliggjort grensedragningen mellom sosiale forhold og sykdom.

Diagnosesystemet ser ut til å omgå et 
utydelig sykdomsbegrep ved å dele inn i sykdomsdiagnoser og symptomdiagnoser. På denne måten vil alle få en diagnosekode ved en legekonsultasjon, men ikke alle diagnoser er like gyldige i trygdemedisinske vurderinger.

\section{Subjektivitet i sykmeldingspraksis}

Et ontologisk objektivt sykdomsideal ligger til grunn for trygdelovgivningen og for selve diagnoseklassifiseringen. I de fleste tilfeller er det imidlertid de subjektive symptomene, og ikke objektive funn, som er legens grunnlag for å stille en diagnose (8). På tross av et tilsynelatende strengt regelverk, viser praksis at mange personer blir langtidssykmeldte og uføre basert på symptomdiagnoser uten objektive funn (3). Hvordan kan vi forstå dette?

Det åpnes i rundskrivet fra rettskildene for bruk av medisinsk klokskap og klinisk skjønn (6), og veilederen setter strenge krav til at legen i sin skjønnsutøvelse ikke skal være farget av egne vurderinger og synspunkter (2). Solli og medforfattere hevder at den norske tradisjonen med et fritt og uregulert medisinskfaglig skjønn nærmest er å betrakte som kunnskapsteoretisk subjektivitet, og etterlyser et mer kvalifisert og mindre vilkårlig skjønn basert på kunnskapsteoretisk objektivitet (10). Det ligger imidlertid i skjønnets natur at det alltid vil ha elementer av vilkårlighet og variasjon, og beslutningssituasjoner med en viss grad av ubestemthet ligger implisitt i legers profesjonsutfoldelse (11).

Sollis operasjonalisering i ulike objektivitets- og subjektivitetsbegreper kan være en nyttig modell for å beskrive glidende overganger fra ontologisk objektive til ontologisk subjektive vurderinger i legers skjønnsutøvelse. Et medisinskfaglig skjønn skal i hovedsak være basert på den enkelte utøvers faglige kunnskap og kompetanse, men $i$ vurderinger av sykdom og arbeidsevne kan det ligge et element av ikke-medisinsk karakter der legens personlige verdiog moralsyn vil være involvert (5). Dette utgjør et betydelig normativt problem, og omtales som skjønnets byrder (11). Det er spesielt tre elementer som påvirker skjønnets byrder. Det er skjønnets kasuistiske trekk, ubestemthet som variasjon i omstendigheter og et alltid tilstedeværende element av førstepersonserfaring (11). Dette betyr at skjønnsutøverens personlige erfaringer med liknende saker, lokale kulturelle omstendigheter og egne livserfaringer vil være med på å påvirke beslutningene. En studie av legers vurderinger ved sykmelding av personer med uspesifikke helseplager bekrefter at det er stor variasjonsbredde $\mathrm{i}$ legers vurderinger i sykmeldingssaker (12). Mange opplever det problematisk å skrive sykmeldingsattest når den kliniske situasjonen ikke er i samsvar med lovverket, og vurderingene synes å være påvirket av legens personlige erfaringer, holdninger og egen personlighet (12).

En konsekvens av regelverkets krav til medisinsk diagnose på trygdeerklæringer kan være en uheldig medikalisering av livsproblemer og sosiale problemer. Praksis viser at mange sykmeldte får en tilfeldig medisinsk merkelapp basert på mindre viktige helseplager, mens den egentlige årsaken til arbeidsuførhet kan være relatert til livsproblemer. Manglende samsvar mellom lovverk og praksis betyr at «kart og terreng» ikke alltid stemmer overens. Det kan synes som om det i sykmeldingspraksis er terrenget som tilpasses kartet og ikke omvendt.

\section{Konklusjon}

Det er ofte manglende samsvar mellom folketrygdens regelverk for sykmelding og helsefaglig praksis. En rekke uspesifikke helseplager lar seg ikke forklare gjennom et ontologisk objektivitetsbegrep. Skjønnsutøvelse utgjør en viktig del av sykmeldingspraksis, men blir i liten grad diskutert. Det er behov for større grad av refleksjon og diskusjon rundt subjektive vurderinger i legers sykmeldingspraksis, likeså rundt hvordan lovverket fungerer, slik at kartet passer bedre med terrenget.
Takk til Hans Magnus Solli for gjennomlesing og verdifulle innspill i sluttfasen av dette manuskriptet.

\section{Irene Øyeflaten (f. 1960)}

er fysioterapeut, cand.san., forskningsleder og stipendiat ved AiR-Nasjonalt kompetansesenter for arbeidsretta rehabilitering. Hun holder på med en doktorgrad ved Psykologisk institutt, Universitetet i Bergen.

Ingen oppgitte interessekonflikter.

Litteratur

1. Lov om folketrygd.www.lovdata.no/all/ tl-19970228-019-021 html (26.11.2010).

2. Mæland JG. Veileder i trygdemedisin 2010. Oslo: Gyldendal Akademisk, 2010: 9-33

3. Ihlebæk C, Brage S, Eriksen HR. Health complaints and sickness absence in Norway, 1996-2003. Occup Med 2007. 57: 43-9.

4. Solli HM. Medisinsk sakkyndighet, objektivitet og rettferdighet i uførepensjonssaker. Tidsskr Nor Lægeforen 2003; 15: 2072-5.

5. Terum LI, Nergård TB. Medisinsk skiønn og rettstryggleik. Legar som portvakter i fordelinga av offentlige goder. Tidsskr Nor Lægeforen 1999; 119: 2192-6

6. NAV. Folketrygdloven. Rundskriv. § 8-4 Arbeidsuførhet. www.nav.no/rettskildene/Rundskriv/ 147679.cms (30.5.2010)

7. Hofmann B. Hva er sykdom? Oslo: Gyldendal Akademisk, 2008

8. Bruusgaard D, Heiberg AN, Lie RK et al. Sykdomsbegrepet i Folketrygden (§8-3). Konsensusrapport til trygderetten. Rapport 1995: 2. Oslo: Gruppe for trygdemedisin, Universitetet i Oslo, 1995

9. KITH. Inklusjonskriterier i ICPC. www. kith.no/ sokeverktoy/icpc-2/bok/inklusjon html (30.5 2010).

10. Solli HM, Barbosa da Silva A, Lie RK et al. Biomedisinsk sykdomsmodell og rettferdig fordeling av uførepensjon. Tidsskr Nor Lægeforen 2005; 23 : 2393-6.

11. Grimen H. Molander A. Profesjon og skjønn. I: Molander A, Terum LI, red. Profesjonsstudier. Oslo: Universitetsforlaget, 2008.

12. Nilsen S, Werner EL, Mæland S et al. Considerations made by the general practitioner when dealing with sick-listing of patients suffering from subjective and composite health complaints. Scand J Prim Health Care 2011; 29: 7-12.

Mottatt 21.12. 2010, første revisjon innsendt 7.4. 2011, godkjent 14.4. 2011. Medisinsk redaktør Are Brean. 